\title{
Four Patients with Trisomy 8 Identified by the Fluorescence and Giemsa Banding Techniques
}

\author{
TORBJÖRN CASPERSSON, JAN LINDSTEN, LORE ZECH, KARIN E. BUCKTON, \\ and WILLIAM H. PRICE
}

\begin{abstract}
From the Institute for Medical Cell Research and Genetics, Medical Nobel Institute, Karolinska Institutet, Department of Clinical Genetics, Karolinska Sjukhuset, Stockholm, Sweden and the Medical Research Council, Clinical and Population Cytogenetics Unit, Western General Hospital, Edinburgh, UK
\end{abstract}

The $\mathrm{C}$ group chromosomes in man cannot be distinguished solely on morphological grounds, thus, the nature of an extra $\mathrm{C}$ chromosome remains unknown unless it is an $\mathrm{X}$ chromosome, which can be identified by its late DNA-replication pattern. Extra autosomes belonging to the $\mathrm{C}$ group have been observed with or without mosaicism in a wide variety of blood disorders ( $c f$, de la Chapelle $e t$ al, 1970; Hellström et al, 1971), in spontaneous abortions (Boué and Boué, 1969), in malformed and/or mentally retarded subjects (Pfeiffer, Schellong, and Kosenow, 1962; El-Alfi, Powell, and Biesele, 1963; Stalder, Bühler, and Weber, 1963; Stolte, Evers, and Blankenborg, 1964; Wolf and Reinwein, 1965; Jalbert et al, 1966; Kerr and Rashad, 1966; Schutt, 1966; Juberg, Gilbert, and Salisbury, 1970), in one female with primary amenorrhoea (Jacobs et al, 1961), and in one apparently healthy female who gave birth to malformed children (Smith, 1964). This great variation in the clinical picture speaks in favour of different $\mathrm{C}$ autosomes having been involved, an hypothesis which has-so far-been impossible to test. The fluorescence and Giemsa banding techniques offer a new possibility to study this problem, and in the present work we describe 4 patients with an extra $\mathrm{C}$ chromosome all identified as No. 8 by these methods. A similar single finding has recently been reported (de Grouchy, Turleau, and Leonard, 1971).

\section{Case Reports}

Case 1. M.R., a boy was born 29 October 1959, two weeks after the expected date of birth. Pregnancy and delivery were normal, birth weight was $4030 \mathrm{~g}$. His father was 22 and his mother 20 years old at the time of his birth. He has one younger healthy brother. The mother had not had any spontaneous abortions. The patient was ascertained because of mental retardation

Received 27 August 1971.
TABLE I

CHROMOSOME COUNTS

\begin{tabular}{|c|c|c|c|c|c|c|}
\hline & \multirow{3}{*}{ Tissue } & \multicolumn{5}{|c|}{ Number of Cells } \\
\hline & & \multicolumn{4}{|c|}{ Number of Chromosomes } & \multirow{2}{*}{ Total } \\
\hline & & 45 & 46 & 47 & 48 & \\
\hline $\begin{array}{c}\text { Case } 1 \\
\text { Mother } \\
\text { Father }\end{array}$ & $\begin{array}{l}\text { Blood } \\
\text { Blood } \\
\text { Blood }\end{array}$ & $\overline{6}^{*}$ & $\begin{array}{r}1 \\
44 \\
50\end{array}$ & $\frac{49}{-}$ & - & $\begin{array}{l}50 \\
50 \\
50\end{array}$ \\
\hline $\begin{array}{l}\text { Case } 2 \\
\text { Mother } \\
\text { Father }\end{array}$ & $\begin{array}{l}\text { Blood } \\
\text { Skint } \\
\text { Blood } \\
\text { Blood }\end{array}$ & $\begin{array}{l}-3 \\
3 \\
1\end{array}$ & $\begin{array}{r}3 \\
14 \\
47 \\
49\end{array}$ & $\begin{array}{l}47 \\
13 \\
-\end{array}$ & $\bar{z}$ & $\begin{array}{l}50 \\
30 \\
50 \\
50\end{array}$ \\
\hline Case 3 & Blood & 3 & 15 & 32 & - & 50 \\
\hline $\begin{array}{l}\text { Mother } \\
\text { Father }\end{array}$ & $\begin{array}{l}\text { Blood } \\
\text { Blood } \\
\text { Skin } \\
\text { Skin } \\
\text { Blood } \\
\text { Blood }\end{array}$ & $\begin{array}{l}- \\
4 \\
- \\
-\end{array}$ & $\begin{array}{l}\frac{1}{8 \ddagger} \\
7^{* *} \\
-\end{array}$ & $\begin{array}{l}29 \\
10 \\
16 \\
20 \\
10 \\
10\end{array}$ & $\begin{array}{l}z \\
z \\
z\end{array}$ & $\begin{array}{l}30 \\
10 \\
28 \\
29 \\
10 \\
10\end{array}$ \\
\hline
\end{tabular}

* Four cells lacked one C chromosome.

† Kindly analysed by Dr A. J. Therkelsen, Aarhus, Denmark.

$\mp$ Two cells lacked one $C$ chromosome.

** Three cells lacked one C chromosome.

(chronological age 4.7 years; mental age about 3 on the Merill-Palmer scale), and various anomalies: cryptorchidism, slight hypertelorism, convergent strabismus, curved 5th fingers, dysplastic skeleton, and a rightsided aortic arch probably with a ductus ligament completing a vascular ring around the oesophagus. There were no other obvious malformations; bodyweight was normal.

A $47, \mathrm{XY},+\mathrm{C}^{*}$ chromosome constitution without evidence of mosaicism was found in cells from lymphocyte cultures (Table I). No late replicating $\mathrm{C}$ chromosome was found after 4 hours labelling with tritiated thymidine (Dr Marco Fraccaro, Pavia). Cells from buccal mucosa smears were sex chromatin negative and no drumsticks were found among 600 neutrophils ( $\mathrm{Dr}$ Ursula Mittwoch, London). Lymphocyte cultures from the parents had normal karyotypes.

* The nomenclature suggested at the Fourth Standardization Conference on Human Cytogenetics, Paris, September 1971, has been used throughout. 
Caspersson, Lindsten, Zech, Buckton, and Price

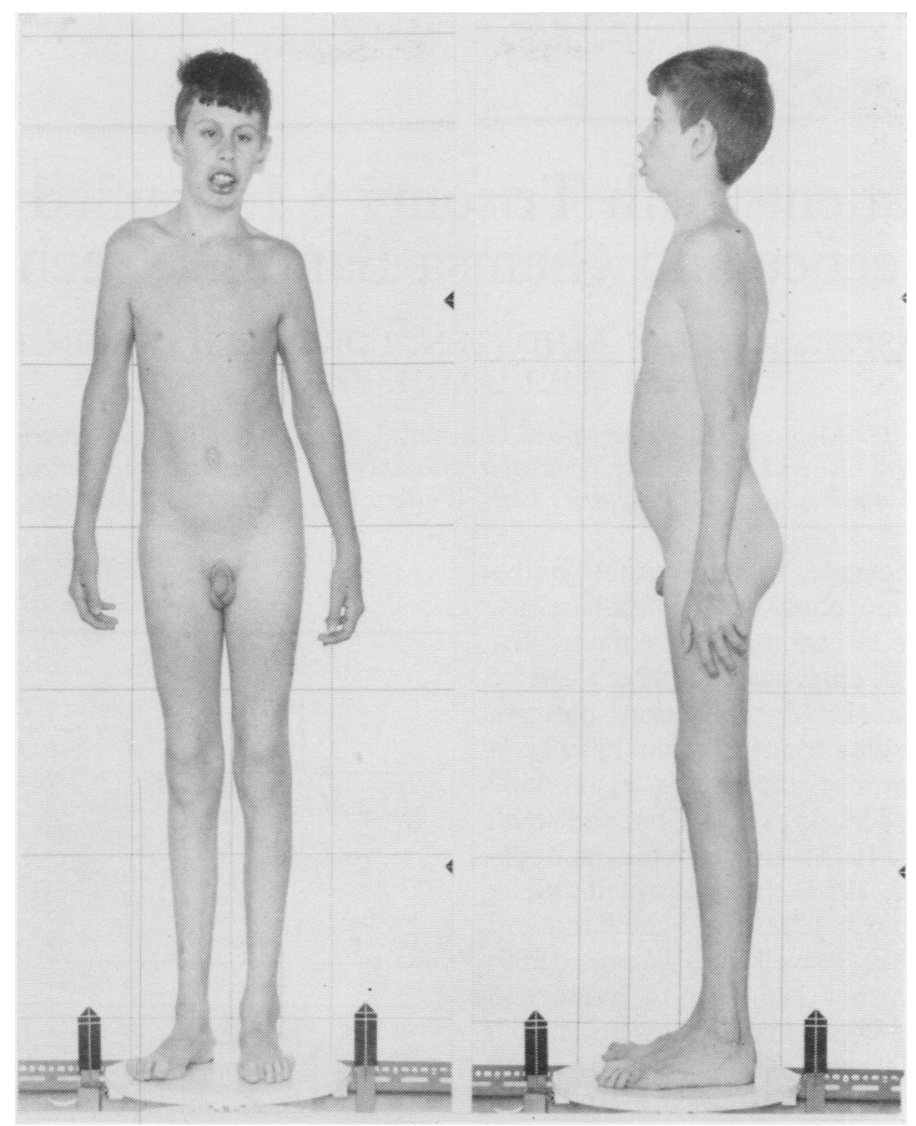

FIG. 1. Case 2 at 16 years 9 months of age (body height $177 \mathrm{~cm}$ ).

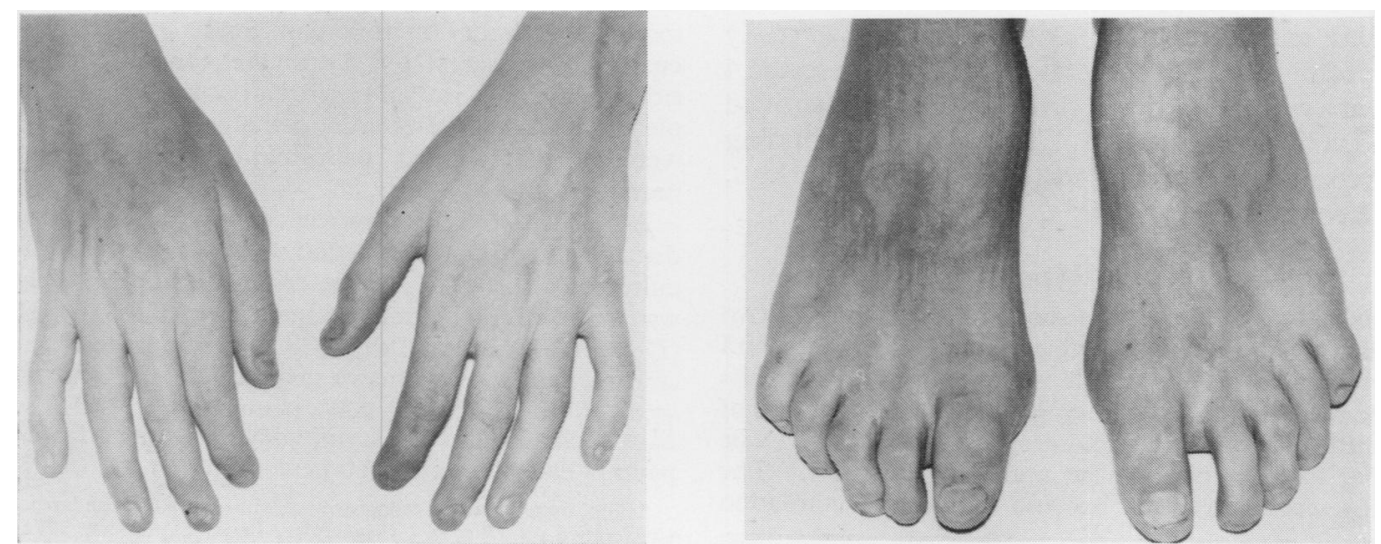

Fig. 2. Case 2. Hands and feet showing curved little fingers and hammer toes. 
Case 2. N.A., a boy was born 13 March, 1954, one week after the expected date of birth. There was a normal pregnancy and delivery with a birth weight of $3940 \mathrm{~g}$. His father was 36 and his mother 33 years old at the time of his birth. He has two older healthy brothers. The mother had not had any spontaneous abortions.

At the last examination at 16 years 9 months (Figs. 1 and 2) the following defects were noted: intellectually slow, impaired speech, agenesis of corpus callosum with hydrocephalus of the communicating type, alternating strabismus, impaired fine movements in the arms and legs, hydronephrosis on the right side, large feet with hammer toes, curved 5th fingers, incomplete closure of the vertebral arches in the 1st and 2nd lumbar vertebrae, and a bone bridge between the spinal processes of the 3rd and 4th lumbar vertebrae. Puberty was delayed. The cytogenetic analysis was made because of the mental retardation plus the various defects.

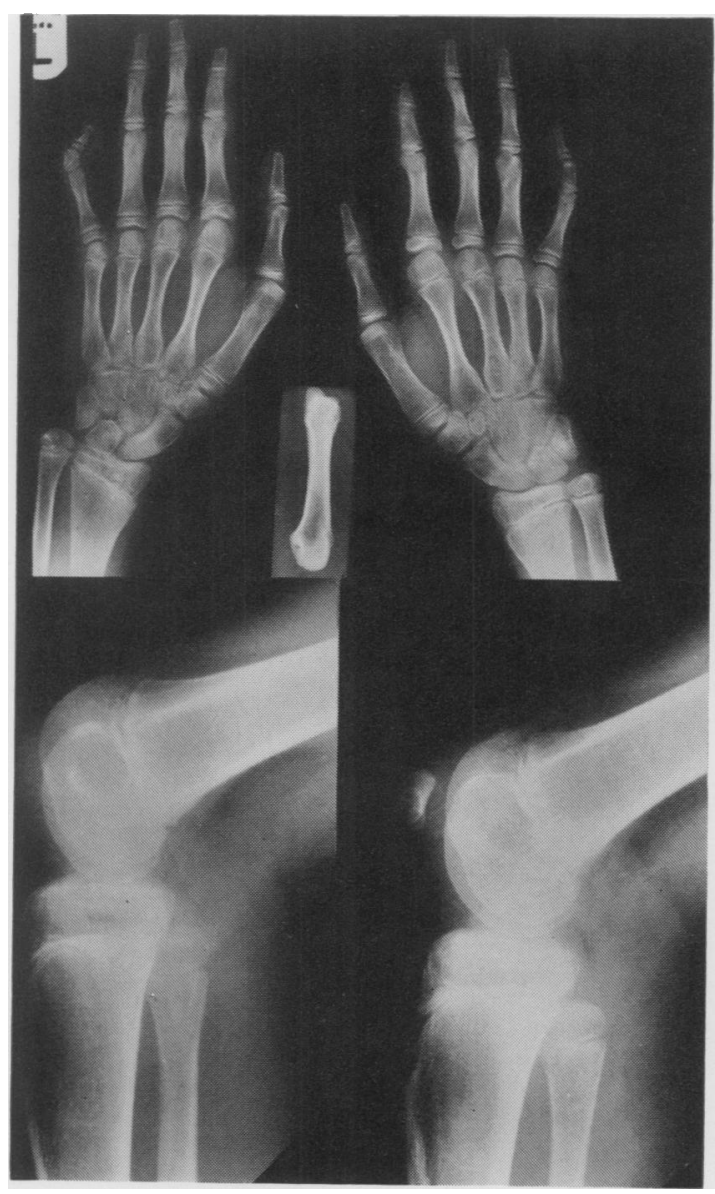

FIG. 3. Case 4. $X$-ray of the hands showing radial deviation, bilateral clinodactyly, and abnormal middle phalanx on left little finger (above). $X$-ray of the knees showing absent right patella (below).
Chromosome studies on cells from lymphocyte and skin cultures revealed a $46, \mathrm{XY} / 47, \mathrm{XY},+\mathrm{C}$ chromosome mosaicism (Table I). The patient was sex chromatin negative in cells from buccal mucosa smears. The parents had normal karyotypes in cells from lymphocyte cultures.

Case 3. M.B.R., a girl was born 7 April 1943, two weeks after the expected date of birth. Pregnancy and delivery were normal and the birth weight was $2870 \mathrm{~g}$. Her father was 44 and mother 42 years old at the time of her birth. She has one older healthy sister who has 2 healthy daughters. The patient had a normal, mental, and physical development and no obvious malformations. She had two missed abortions, in 1968 and 1969, which prompted a cytogenetic analysis. Ovariectomy was performed on the right side in 1969 because of an ovarian cystoma.

A $46, \mathrm{XX} / 47, \mathrm{XX},+\mathrm{C}$ chromosome mosaicism was found in cells from lymphocyte cultures (Table I). Only one late replicating chromosome was found in the cells with $\mathbf{4 7}$ chromosomes after labelling for 4 hours with tritiated thymidine (Dr Marco Fraccaro, Pavia). Cells from buccal mucosa smears revealed only one sex chromatin body.

Case 4. R.McM., a boy was born in May 1958. This patient has been reported elsewhere (Schutt, 1966) as he was ascertained during a survey of children with cleft palate and other congenital abnormalities. He was

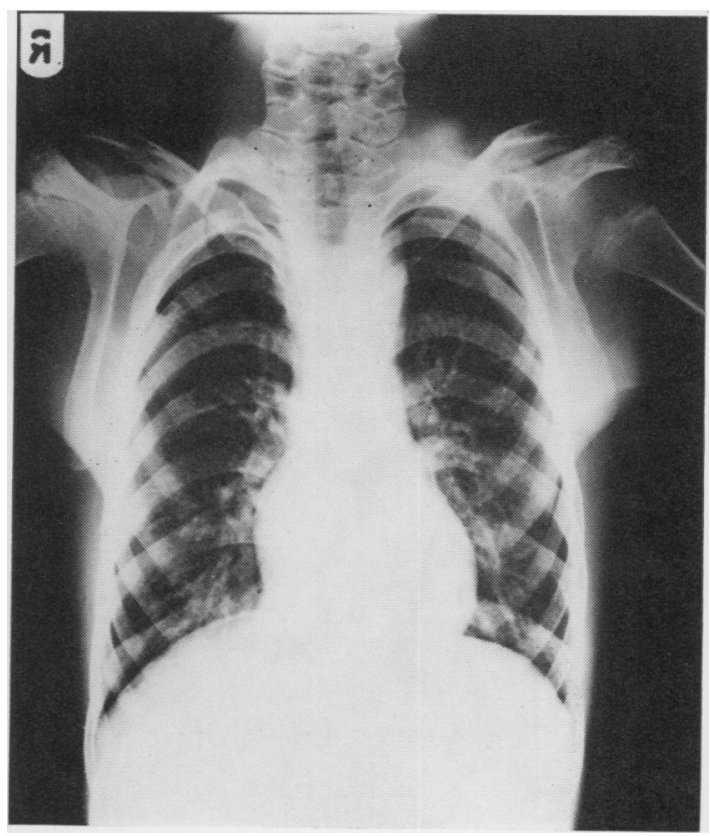

Fig. 4. Case 4. $X$-ray of the chest showing spinal dysraphism and abnormal right 1 st and 2 nd ribs and possible left-sided superior vena cava. 
the 3rd in a sibship of 3. At the time of his birth his parents were both aged 35 . The pregnancy and delivery were uneventful and at birth he weighed $2770 \mathrm{~g}$.

$\mathrm{He}$ is mentally retarded and has multiple skeletal and soft tissue abnormalities. At birth he had a cleft of the soft palate, which was repaired at the age of 2 , and a discharging midline sinus at the bridge of the nose which closed spontaneously by the age of 10 . He has bilateral clinodactyly and the middle phalanx of the left little finger is abnormally short and has 2 centres of ossification (Fig. 3). The bodies of the 1st, 2nd, and 3rd dorsal vertebrae are bifid (Fig. 4). On the right side a cervical rib fuses with the first rib which is thickened and articulated at its anterior end with a widened third rib. The soft tissue abnormalities include abnormally large and prominent ears and a thick and everted lower lip which is possibly due to a small mandible (Fig. 5). A marked radial deviation of the hands and prominence of the heads of the fibulae are probably due to increased laxity of the joint capsules. There is a single palmar crease on the left hand. At the age of 13 years his IQ (Stanford Binet) was 53. His articulation is poor and he is liable to bouts of uncontrollable temper. Up to the age of 13 years his height and weight have been within one standard deviation of the mean for Edinburgh children.

There is no evidence of a congenital cardiac lesion but the upper mediastinum appears abnormal on the chest $x$-ray which may be due to a left superior vena cava and hypoplasia of the aorta. This possibility will be investigated further when he is older.

Chromosome studies on the patient when he was 6 years old on 2 separate peripheral blood cultures and 2 skin cultures showed a chromosome constitution of $47, \mathrm{XY},+\mathrm{C}$. There was no evidence of mosaicism, and no late replicating $\mathrm{C}$ group chromosome was found after four hours labelling with tritiated thymidine. Cells from buccal mucosa were sex chromatin negative and no drumsticks were found. Chromosome studies on peripheral blood leucocytes from both parents showed that they had karyotypes indistinguishable from normal.

\section{Analysis of the Fluorescence and Giemsa Banding Patterns}

The fluorescence analysis of chromosomes was made on cells from lymphocyte cultures (Caspersson, Zech, and Johansson, 1970; Caspersson, Lomakka, and Zech, 1971). The extra chromosome was interpreted as a No. 8 in all 4 cases with no evidence of structural rearrangements (Fig. 6). In case 4 the ASG technique (Sumner, Evans, and Buckland, 1971) showed a similar result to the fluorescent analysis of this case (Fig. 7).

\section{Discussion}

The present 4 cases with $C$ trisomy all turned out to have an extra, apparently homologous chromosome No. 8. Mosaicism could be demonstrated in 2 of the 4 patients in analogy with one recently published case (de Grouchy et al, 1971). It has previously not been possible to identify extra autosomes in the $\mathrm{C}$ group in man, ie, to decide whether such a chromosome is structurally abnormal or homologous

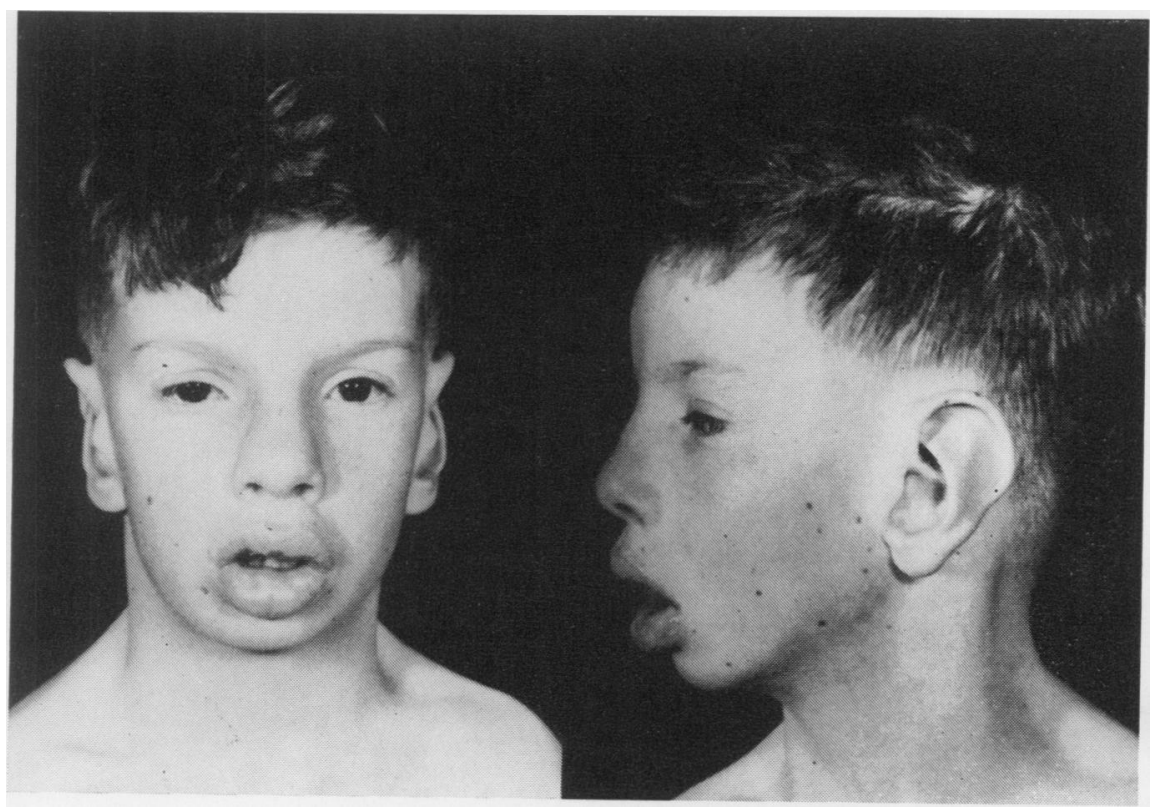

Fig. 5. Case 4. Front and side view of face showing thickened and everted lower lip, large ears, and right internal strabismus. 


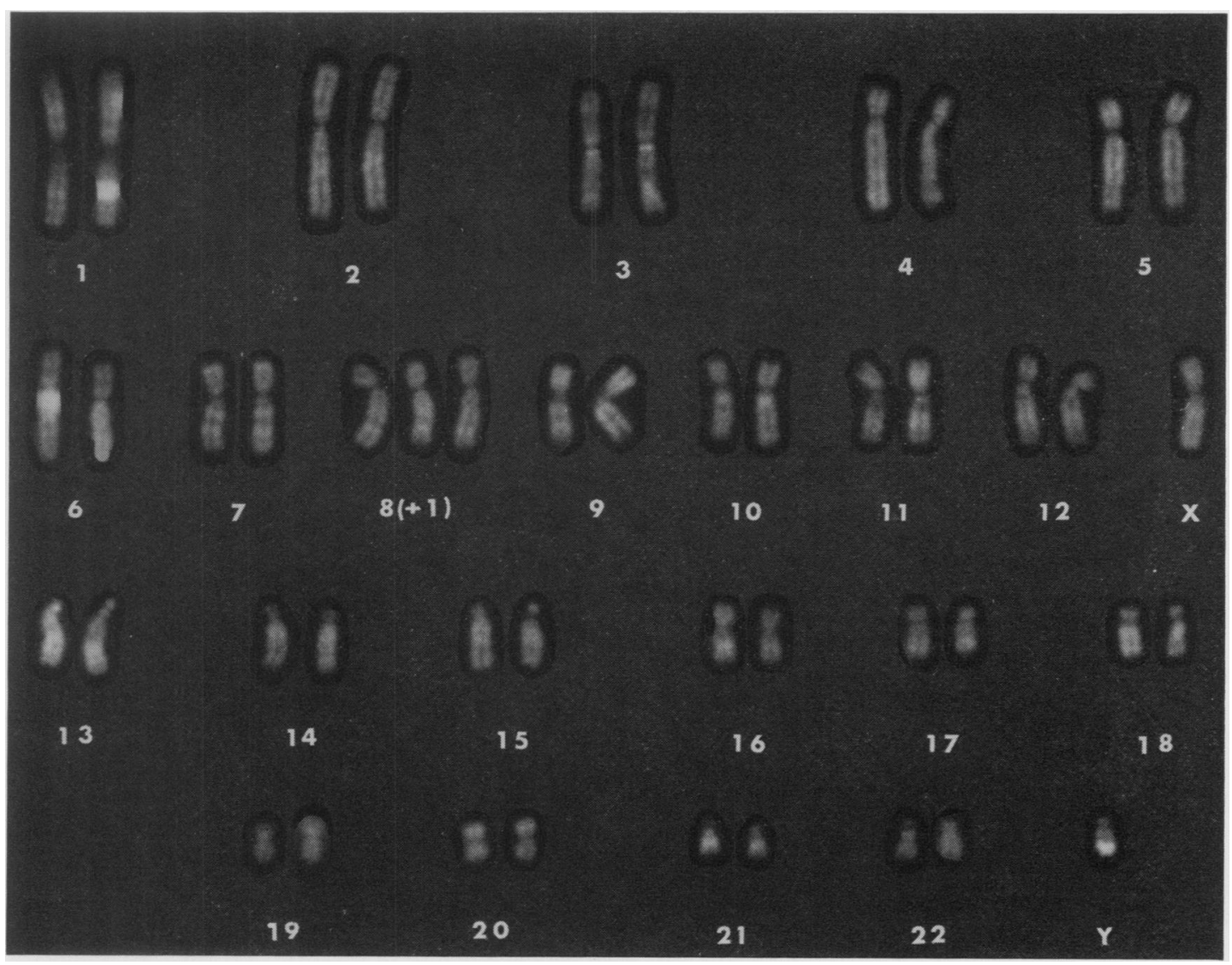

FIG. 6. Case 2. Karyotype of a cell stained with quinacrine mustard.

to one of the 7 chromosomes in this group. The wide variation in the clinical picture of the patients has favoured a mixed group of chromosome abnormalities. On the other hand, most cases in the literature have had a $46 / 47,+C$ mosaicism and the clinical variations could then be due to differences in the proportion of abnormal cells in various tissues even if the extra chromosome was the same.

The 3 males in the present study suffered from mental retardation, not amounting to severe subnormality, concomittant strabismus, clinodactyly, and other skeletal defects including spinal dysraphism in at least 2 of the 3 . Congenital heart lesions were not observed in any of them but it could be significant that 2 of them may have abnormalities of the great vessels at their origin. It is of interest to note that 5 previously published reports of males with a $46 / 47$, $+C$ mosaicism were ascertained because of mental retardation (Pfeiffer et al, 1962;
El-Alfi et al, 1963; Stolte et al, 1964; Schutt, 1966; de Grouchy et al, 1971). Other features which have been reported repeatedly include skeletal and joint defects (Pfeiffer et al, 1962; El-Alfi et al, 1963; Stolte et al, 1964; Jalbert et al, 1966; Gustavson, Hagberg, and Santesson, 1967; Juberg et al, 1970). Cryptorchidism has also been noted (Pfeiffer et al, 1962; El-Alfi et al, 1963; Stalder et al, 1963; Schutt, 1966). Agenesis of corpus callosum, as found in one of our cases, has also been found previously in a boy with mosaicism and C trisomy (Gustavson et al, 1967). Furthermore, the present female had two missed abortions, and another female was selected for chromosome analysis because she had a malformed child (Smith, 1964). These findings imply that chromosome No. 8 might have been involved in several of the previously published cases. Further studies using improved techniques for chromosome identification must be made in 


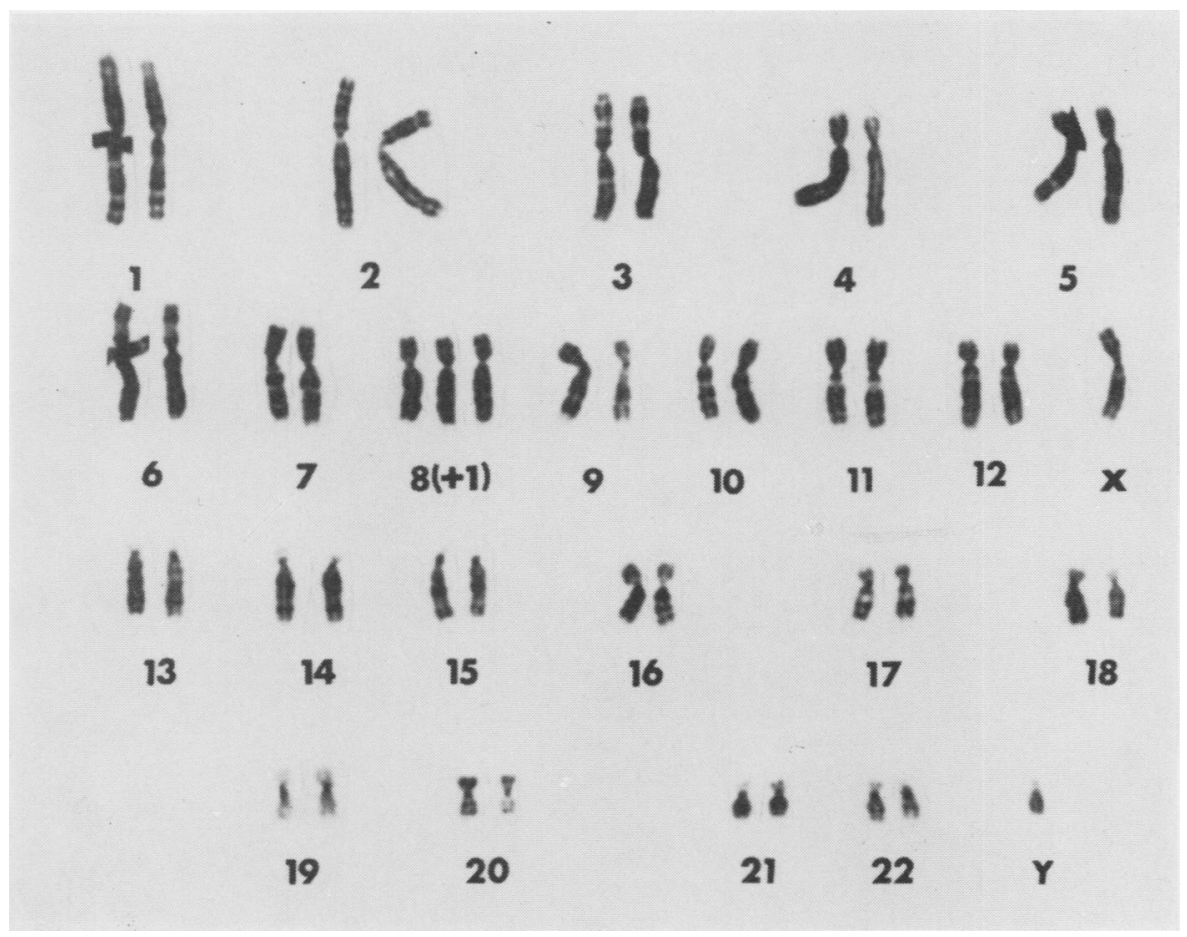

Fig. 7. Case 4. Karyotype of a Giemsa banded cell.

order to evaluate whether it will also be possible to delineate a trisomy 8 syndrome by phenotypic criteria.

It should be mentioned that the mean maternal age was $32 \cdot 2$ years and the mean paternal age 33.2 years for the 4 patients plus the one previously published (de Grouchy et al, 1971). This observation indicates that an increased parental age might also be of aetiological significance for the origin of trisomy 8. However, at present it is impossible to elucidate the origin of the mosaicism. The original zygote could have had 46 or 47 chromosomes. In the first case mitotic non-disjunction would have had to occur after the first division and a cell with $45,-8$ must have been eliminated at some further stage of development.

Chromosome No. 8 is the largest autosome so far found among liveborn trisomics in man, which indicates that this chromosome does not seriously upset the viability of the cells and would appear to be much less deleterious to the individual than trisomy $D, E$, or $G$. On the other hand, most cases reported have been mosaics which might mean that a zygote with only trisomic cells is considerably unbalanced. The present cases 1 and 4 who only had trisomic cells do not support this hypothesis.

\section{Summary}

The fluorescence pattern of chromosomes was analysed in 4 subjects with an extra $\mathrm{C}$ autosome which was found to be homologous with chromosome No. 8 in all the cases. The findings point to the existence of a trisomy 8 syndrome in man, and the clinical features of this syndrome are discussed.

The expenses for the study of the first 3 cases were covered by grants from the Swedish Cancer Research Foundation to the Department of Cell Research and Genetics and from the Swedish Medical Research Council to the Department of Clinical Genetics. The authors would like to thank Professors John Lind and Lars Leksell and Dr Gunnar Tillinger, Stockholm, for allowing us to study case 1,2 , and 3 respectively, and $\mathrm{Dr}$ A. T. Sumner (MRC Clinical and Population Cytogenetics Unit) for the karyotype of the Giemsa banded cell from case 4.

\section{REFERENCES}

Boué, J. G. and Boué, A. (1969). Fréquence des aberrations chromosomiques dans les avortements spontanés humains. Comptes Rendus Hebdomadaires des Séances de l'Académie des Sciences, 269, 283-288.

Caspersson, T., Lomakka, G., and Zech, L. (1971). The 24 fluorescence patterns of the human metaphase chromosomes-distinguishing characters and variability. Hereditas, Genetiskt Arkiv, 67, 89-102. 
Caspersson, T., Zech, L., and Johansson, C. (1970). Analysis of the human metaphase chromosome set by aid of DNA-binding fluorescent agents. Experimental Cell Research, 62, 490-492.

De Grouchy, J., Turleau, C., and Leonard, C. (1971). Etude en fluorescence d'une trisomie $C$ mosaique probablement $8: 46, X Y$ 47,XY, ?8 +. Annales de Génétique, 14, 69-72.

De la Chapelle, A., Wennström, J., Wasastjerna, C., Knutar, F., Stenman, U. H., and Weber, T. H. (1970). Apparent C trisomy in bone marrow cells. Scandinavian fournal of Haematology, 7, 112-122.

El-Alfi, O., Powell, H. C., and Biesele, J. J. (1963). Possible trisomy in chromosome group 6-12 in a mentally retarded patient. Lancet, $1,700$.

Hellström, K., Hagenfeldt, L., Larsson, A., Lindsten, J., Sundelin, P., and Tiepolo, L. (1971). An extra C chromosome and various metabolic abnormalities in the bone marrow from a patient with refractory sideroblastic anaemia. Scandinavian fournal of Haematology, 8, 293-306.

Gustavson, K. H., Hagberg, B., and Santesson, B. (1967). Mosaic trisomy of an autosome in the 6-12 group in a patient with multiple congenital anomalies. Acta Paediatrica Scandinavica, 56, 681686.

Jacobs, P. A., Harnden, D. G., Buckton, K. E., Court Brown, W. M., King, M. J., McBride, J. A., McGregor, T. N., and McLean, N. (1961). Cytogenetic studies in primary amenorrhoea. Lancet, 1 , 1183-1189.
Jalbert, P., Jobert, J., Patet, J., Mouriquand, C., and Roget, J. (1966). Un nouveau cas de trisomie présumée 6-12. Annales de Génétique, 9, 109-112.

Juberg, R. C., Gilbert, E. F., and Salisbury, R. S. (1970). Trisomy $\mathrm{C}$ in an infant with polycystic kidneys and other malformations. Fournal of Pediatrics, 76, 598-603.

Kerr, M. G. and Rashad, M. N. (1966). Autosomal trisomy in a discordant monozygotic twin. Nature, 212, 726-727.

Pfeiffer, R. A., Schellong, G., and Kosenow, W. (1962). Chromosomen Anomalien in den Blutzellen eines Kindes mit multiplen Abartungen. Klinische Wochenschrift, 40, 1058-1067.

Schutt, W. (1966). In The Causes and Natural History of Cleft Lip and Palate, ed. by C. M. Drillien, T. T. S. Ingram, and E. M. Wilkinson, p. 217. Livingstone, London and Edinburgh.

Smith, D. W. (1964). Autosomal abnormalities. American fournal of Obstetrics and Gynecology, 90, 1055-1077.

Stalder, G. R., Bühler, E. M., and Weber, J. R. (1963). Possible trisomy in chromosome group 6-12. Lancet, 1, 1379.

Stolte, L., Evers, J., and Blankenborg, G. (1964). Possible trisomy in chromosome group 6-12 in a normal woman. Lancet, 2, 480.

Sumner, A. T., Evans, H. J., and Buckland, R. A. (1971). New technique for distinguishing between human chromosomes. Nature New Biology, 232, 31-32.

Wolf, U. and Reinwein, H. (1965). Chromosomenmosaik C-trisomie/normal. Humangenetik, 1, 686-687. 
and isochromosome for the long arm of 21 were excluded by the clinical findings, dermal patterns (Walker index), and the size of the abnormal chromosome. Trisomy 22 with a G/G translocation was ruled out by the size of the abnormal chromosome. Trisomy 16 with monosomy $\mathrm{G}$ was excluded because the abnormal chromosome was always metacentric and slightly bigger than the number 16 . Trisomy 17 with $17 / G$ translocation or monosomy G with isochromosome for short arm of one of the group C or group B chromosomes remain possibilities.

At present, classification of this karyotype is inadvisable, especially in view of inconclusive autoradiographic studies and inadequate banding pattern of the chromosomes. Perhaps similar cases will be reported.

\section{Summary}

We report the case of an unusual-looking infant with multiple congenital anomalies such as colo- boma of the iris, corneal opacities, congenital heart defect, hepatosplenomegaly etc, who had an abnormal karyotype which appears to be unique and remains unclassified.

The authors wish to thank Dr Herbert A. Lubs, Jr of the University of Colorado Medical Center, Colorado, for his suggestions; and Donna Nerima and Carol Crabtree for their technical assistance.

Rawatmal B. Surana,* Trevor M. Hunt, and PATRICK E. CONEN

Departments of Pathology and Paediatrics and the Research Institute, The Hospital for Sick Children, and the Departments of Pathology and Paediatrics, University of Toronto, Ontario, Canada

* Present Address: Howard University College of Medicine and Freemen's Hospital, 6th and Bryant Sts, NW Washington, DC 20001, USA.

\section{Corrigenda}

On the Pathogenesis of Favism by Ernesto Sartori, December 1971, vol. 8, pp. 462-467.

The last sentence in the section on the X-linked and haemolytic predisposition (p. 465, column 2) should read:

For instance, a difference ranging between 0.198 and 0.290 for G6PD deficiency corresponds to a difference ranging between as little as 0.107 and 0.120 for favism in Seneghe and Lodé respectively

Four Patients with Trisomy 8 Identified by the Fluorescence and Giemsa Banding Techniques by Torjbörn Caspersson, Jan Lindsten, Lore Zech, Karin E. Buckton, and William H. Price, March 1972, vol. 9, pp. 1-7.

The 10 cells counted and analysed from both the father and the mother of case 4 contained 46 chromosomes and not $\mathbf{4 7}$ as shown in Table I (p. 1). 